\title{
PENERAPAN RADIO FREQUENCY IDENTIFICATION DALAM MEMBANGUN SISTEM KEAMANAN DAN MONITORING SMART LOCK DOOR BERBASIS WEBSITE
}

\author{
Ridho Syukuryansyah ${ }^{1}$, Didik Setiyadi ${ }^{2}$, Syahbaniar Rofiah $^{3}$ \\ ${ }^{1,2}$ Teknik Informatika, ${ }^{2}$ Manajemen Informatika, Universitas Bina Insani Bekasi, Indonesia \\ Correspondence email: rsyahbaniar@gmail.com
}

Article history: $\quad$ Submission date: Okt 27, $2020 \quad$ Revised date: Nov 11, $2020 \quad$ Accepted date: Nov 24, 2020

\begin{abstract}
Technology in this modernization era helps many workers and human needs. Technology has explored various fields and one cannot separate it from the security system. The need for increased security is based on the need for humans to feel comfortable with their assets in a safe condition and can be monitored from anytime and anywhere. The problem in this study is that conventional room security systems that use padlocks cannot provide a complete sense of security because they cannot be monitored remotely, the use of conventional room security systems that are not equipped with preventive measures or theft warning systems cannot minimize security threats, there is no monitoring. door opening activities in conventional room security systems make it difficult to trace the perpetrators of theft by internal parties. This study aims to build a security system using RFID and Arduino which can be monitored via the website. An early warning system against unknown objects is also embedded in it using a magnetic switch sensor on the door, a buzzer to create sound frequencies that can attract the attention of the surrounding environment and the Arduino camera module to capture images of objects. The results of this study, RFID can facilitate access in and out of doors and increase security compared to conventional locks. Only registered / recognized objects can access the room through the door. In and out activities are monitored via a website that can be accessed anytime and anywhere.
\end{abstract}

Keywords: Arduino, Monitoring, RFID, Security Systems, Websites.

\begin{abstract}
ABSTRAK
Teknologi di era modernisasi ini banyak membantu pekerja serta kebutuhan manusia. Berbagai bidang sudah dirambah dengan teknologi dan tak bisa dilepaskan lagi salah satunya sistem keamanan. Perlunya peningkatan keamanan didasarkan pada kebutuhan manusia atas rasa nyaman terhadap aset yang dimilikinya dalam keadaan aman dan dapat dimonitoring dari kapanpun dan dimanapun. Permasalahan dalam penelitian ini adalah sistem keamanan ruangan konvensional yang menggunakan gembok tidak bisa memberikan rasa aman sepenuhnya karena tidak dapat dipantau dari jarak jauh, penggunaan sistem keamanan ruangan konvensional yang tidak dilengkapi dengan tindakan pencegahan atau sistem peringatan pencurian tidak dapat meminimalisir ancaman keamanan, tidak adanya pemantauan aktivitas buka pintu pada sistem keamanan ruangan konvensional mempersulit dalam melacak pelaku pencurian yang dilakukan oleh pihak internal. Penelitian ini bertujuan untuk membangun sistem keamanan dengan menggunakan $R F I D$ dan Arduino yang dapat dimonitoring melalui website. Sistem peringatan dini terhadap objek yang tidak dikenal juga disematkan didalamnya menggunakan magnetic switch sensor pada pintu, buzzer untuk menciptakan frekuensi suara yang dapat menarik perhatian lingkungan sekitar serta modul kamera Arduino untuk menangkap gambar objek. Hasil dari penelitian ini RFID dapat memudahkan akses keluar masuk pintu serta meningkatkan keamanan dibandingakan dengan kunci konvensional. hanya objek yang didaftarkan atau dikenal saja yang dapat mengakses ruangan tersebut melalui pintu tersebut. Aktivitas keluar masuk dipantau melalui website yang dapat diakses kapan saja dan dimana saja.
\end{abstract}

Kata Kunci: Arduino, Monitoring, RFID, Sistem Keamanan, Website. 


\section{PENDAHULUAN}

Keamanan merupakan salah satu kebutuhan manusia yang menunjang kenyamanan bagi manusia dalam melindungi asetnya. Aset yang dapat dipantau dan dijaga dengan baik dapat meningkatkan rasa aman bagi pemiliknya. Penjagaan dan pemantauan untuk menjaga aset tersebut harus dilakukan terus menerus dengan teliti agar rasa aman tetap terjaga. Ancaman keamanan yang dapat terjadi kapan saja membuat orang sulit mendapatkan rasa aman. Segala aktivitas keseharian pada era modernisasi ini tidak luput dari teknologi yang memiliki peranan penting. Hadirnya alat yang dapat memberikan kemudahan bagi segala aspek kehidupan membuat teknologi tidak dapat dipisahkan dalam kehidupan pada era modernisasi ini. Segala hal dapat dilakukan menjadi lebih mudah berkat hadirnya teknologi yang membantu manusia dalam memenuhi kebutuhannya. Teknologi yang terus berkembang hingga saat ini telah banyak menghasilkan alat untuk mempermudah kegiatan manusia bahkan menggantikan peran manusia dalam suatu fungsi tertentu (Sani, 2018).

Arduino adalah suatu open-source platform elektronik yang berbasis kemudahan penggunaan (easy to easy) baik hardware maupun software (Ahyadi, 2018). Berdasarkan pengertian tersebut, Arduino sebagai perangkat elektronika open source memungkinkan siapapun untuk memanfaatkannya untuk membuat alat elektronika yang dapat membantu manusia dalam memenuhi kebutuhannya, salah satunya untuk membuat sistem keamanan ruangan dengan smart lock door berbasis RFID (Radio Frequency identification). Beberapa ukuran label RFID dapat mendekati ukuran sekecil butir kertas. Label yang pasif tidak membutuhkan sumber tenaga sedangkan label yang aktif membutuhkan sumber tenaga untuk berfungsi (Setiawardhana et al., 2019).

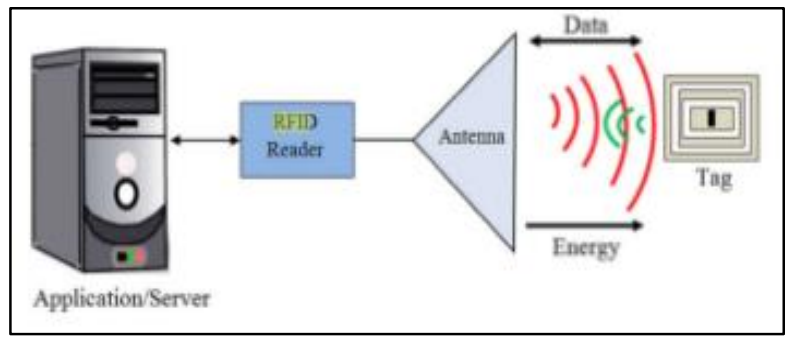

Sumber: (Yudhanto \& Azis, 2019)

Gambar 1. Sistem RFID

Keterangan gambar 1 merupakan sistem RFID terdiri dari 4 komponen yaitu tag, antena, software dan pembaca RFID (Reader).
Sifat open source yang dimiliki oleh Arduino sebagai sebuah mikrokontroller serta teknologi RFID berbasis gelombang radio yang praktis dalam mengidentifikasi sebuah objek dapat dimanfaatkan untuk membangun sistem keamanan ruangan yang aman dan nyaman. RFID pada sistem ini berfungsi sebagai alat untuk mengidentifikasi obyek yang masuk kedalam ruangan. Selain penggantian RFID sebagai sistem penguncian, sistem ini juga dapat melakukan tindakan preventif dengan membunyikan suara serta mengirimkan notifikasi pada pengguna. Apabila terdapat objek yang tidak dikenali masuk kedalam ruangan maka speaker akan berbunyi dan akan mengirimkan notifikasi berupa email, tujuannya untuk memberikan peringatan. Kondisi tersebut akan ditentukan oleh RFID dengan bantuan magnetic sensor untuk mengetahui kondisi pintu pada suatu ruangan dibuka secara paksa atau tidak. Website sebagai media yang dapat diakses kapan saja dan dimana saja juga dimanfatkan sebagai media otentikasi sekunder. Hal yang dapat dipantau melalui website tersebut adalah informasi mengenai kapan terakhir pintu dibuka atau ditutup. Sistem ini diharapkan dapat mempermudah akses serta dapat meningkatkan keamanan pada suatu ruangan dengan memanfaatkan teknologi dan media elektronik yang dapat dikendalikan dan diawasi dari jarak jauh secara terus menerus nonstop (Wiranata et al., 2020).

Pada penelitian sebelumnya terdapat Sistem keamanan pintu dimana pun diperlukan, karena untuk melindungi bagian bagian yang tersimpan, baik itu pada perumahan, pergudangan, perkantoran, atau di dunia industri (Mulyati Sumardi, 2019). RFID dan Fingerprint sensor sebagai media autentifikasinya supaya pengguna atau orang yang akan mengakses ke dalam ruangan tersebut lebih terseleksi karena orang - orang yang memiliki akses atau orang yang ID dan sidik jarinya terdaftar yang dapat mengakses ruangan tersebut. Website berfungsi sebagai media monitoring dan penyimpanan data untuk mengakses aktivtias keluar masuk ruangan. Kartu RFID dapat membaca dengan baik pada jarak $2,5 \mathrm{~cm}$ dengan rata-rata pembacaan pada setiap user selama 0,7 detik (Daulay \& Alamsyah, 2019). Dengan kemajuan teknologi tersebut pada era sekarang ini komunikasi bukan hanya digunakan untuk komunikasi antar sesama manusia saja, melainkan antara manusia dengan alat-alat kontrol, seperti sistem pintu otomatis berbasis Radio Frequency Identification (RFID) dengan Arduino Uno R3. Banyaknya siswasiswa yang berkunjung ke ruang kelas lain ketika jam mata pelajaran guru yang kosong. Terjadinya beberapa kali kehilangan peralatan yang ada di ruang kelas atau di ruang labolatorium sehingga keamanannya kurang terjaga dengan baik (Sofyan et al., 2017). 
Berdasarkan latar belakang yang telah dijelaskan sebelumnya, terdapat beberapa masalah yang dapat diidentifikasi: Sistem keamanan ruangan konvensional yang menggunakan gembok tidak bisa memberikan rasa aman sepenuhnya karena tidak dapat dipantau dari jarak jauh, penggunaan sistem keamanan ruangan konvensional yang tidak dilengkapi dengan tindakan pencegahan atau sistem peringatan pencurian tidak dapat meminimalisir ancaman keamanan, tidak adanya pemantauan aktivitas buka pintu pada sistem keamanan ruangan konvensional mempersulit dalam melacak pelaku pencurian yang dilakukan oleh pihak internal.

Adapun tujuan penelitian ini yaitu pertama, membangun sistem keamanan pintu menggunakan RFID sebagai media otentikasinya, kedua membangun sistem peringatan dini terhadap orang yang tak dikenali dan yang terakhir membangun sistem monitoring terhadap aktivitas keluar masuk ruangan.

\section{METODE PENELITIAN}

Metode pengembangan yang digunakan dalam penelitian ini adalah metode Prototype yang juga berfungsi sebagai kerangka kerja yang menjelaskan bagaimana proses penelitian ini berlangsung sehingga proses penelitian ini dapat dikerjakan sesuai dengan tahapan yang berurutan (Budiyantara et al., 2020).

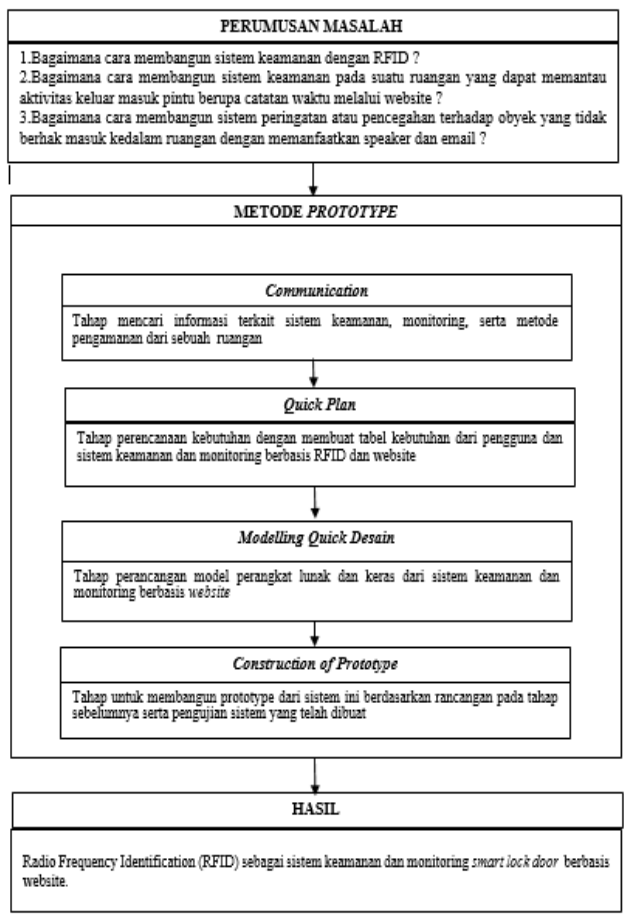

Sumber: (Ridho Syukuryansyah et al. 2020)

Gambar 2. Kerangka Pemikiran Penelitian
Keterangan gambar 2 menguraikan bahwa tahap awal penelitian dimulai dari tahap communication, yaitu tahap mencari informasi terkait sistem keamanan, monitoring, serta metode pengamanan dari sebuah ruangan. Selanjutnya adalah tahap quick modelling yaitu tahap perencanaan kebutuhan dengan membuat tabel kebutuhan dari pengguna dan sistem keamanan dan monitoring berbasis RFID dan website. Modelling quick design adalah Tahap perancangan model perangkat lunak dan keras dari sistem keamanan dan monitoring berbasis website. Construction of prototype adalah tahap untuk membangun prototype dari sistem ini berdasarkan rancangan pada tahap sebelumnya serta pengujian sistem yang telah dibuat. Mengimplementasi perangkat keras (hardware) dan perangkat lunak (software) berdasarkan pada rancangan yang telah dibuat pada tahap sebelumnya serta pengujian dari prototype yang telah dibuat terhadap aspek aspek yang direncanakan supaya dapat berjalan dengan baik dan sesuai tujuan. Sehingga dapat menghasilkan dan mengimplementasikan sistem keamanan dan monitoring smart lock door yang mampu mengidentifikasi pihak yang tak berhak masuk, serta memonitoring semua aktivitas keluar masuk pintu dan dapat memberikan peringatan apabila terdapat akses yang tidak dikenal.

\section{HASIL DAN PEMBAHASAN}

Proses serta tahapan yang digunakan untuk membangun sistem smart lock door ini didasarkan pada metode prototype. Berikut adalah tahapan dalam setiap proses nya:

Pada tahap Pertama communication dalam tahapan ini Komunikasi dilakukan untuk mengumpulkan informasi sistem yang sedang berjalan pada gudang RT 8 RW 26, Wanasari, Cibitung. Informasi yang didapatkan berupa proses untuk membuka pintu gudang. Gudang menggunakan kunci konvensional sehingga pintu dibuka dengan membuka kunci dengan mata kunci (Galih Surono, 2020).

Berdasarkan informasi mengenai sistem yang sedang berjalan didapatkan sebuah user requirement untuk meningkatkan sistem keamanan gudang yang dapat dipantau dari jauh karena gudang tidak diawasi 24 jam dengan cara mendeteksi orang asing yang masuk serta memberikan peringatan berupa suara dan email sebagai langkah antisipasi dari pencurian. Selain itu, mencatat segala aktivitas keluar masuk dari jarak jauh, untuk melacak pelaku apabila terjadi kehilangan barang pada waktu tertentu. Kebutuhan sistem yang diinginkan pengguna dapat dilihat pada tabel 1. 
Tabel 1. Kebutuhan Pengguna

\begin{tabular}{|c|c|c|}
\hline No & Kebutuhan & Deskripsi \\
\hline 1 & $\begin{array}{l}\text { Alat autentikasi } \\
\text { elektronik }\end{array}$ & $\begin{array}{l}\text { Alat yang dapat } \\
\text { mengidentifikasi } \\
\text { objek berbasis } \\
\text { elektronik sehingga } \\
\text { datanya dapat } \\
\text { disimpan untuk } \\
\text { mencatat } \\
\text { aktivitasnya }\end{array}$ \\
\hline 2 & $\begin{array}{l}\text { Registrasi banyak kunci } \\
\text { untuk banyak pengguna }\end{array}$ & $\begin{array}{l}\text { Untuk } \\
\text { mempermudah } \\
\text { akses, setiap } \\
\text { pengurus } \\
\text { memegang satu } \\
\text { kunci, serta fitur } \\
\text { registrasi kunci } \\
\text { baru untuk lebih } \\
\text { memudahkan }\end{array}$ \\
\hline 3 & $\begin{array}{l}\text { Monitoring aktivitias } \\
\text { online }\end{array}$ & $\begin{array}{l}\text { Untuk monitoring } \\
\text { aktivitas keluar } \\
\text { masuk pengurus ke } \\
\text { dalam gedung }\end{array}$ \\
\hline 4 & $\begin{array}{l}\text { Notifikasi melalui email } \\
\text { jika terjadi pembukaan } \\
\text { secara paksa }\end{array}$ & $\begin{array}{l}\text { Digunakan untuk } \\
\text { mengetahui secara } \\
\text { dini jika terjadi } \\
\text { pembukaan pintu } \\
\text { secara paksa }\end{array}$ \\
\hline 5 & Alarm Suara & $\begin{array}{l}\text { Digunakan untuk } \\
\text { memberikan } \\
\text { peringatan pada } \\
\text { warga sekitar }\end{array}$ \\
\hline 6 & Log aktivitas buka pintu & $\begin{array}{l}\text { Digunakan untuk } \\
\text { menyimpan data } \\
\text { riwayat buka tutup } \\
\text { pintu }\end{array}$ \\
\hline
\end{tabular}

Sumber: (Ridho Syukuryansyah et al. 2020)

Tahapan kedua yaitu Quick Plan dalam tahapan ini terdapat 2 perencanaan kebutuhan dalam membangun sistem ini yaitu, yaitu perencanaan kebutuhan perangkat keras dan kebutuhan perangkat lunak. Perencanaan kebutuhan perangkat keras dan perangkat lunak ini dibuat berdasarkan kebutuhan penggunaan yang didapat pada tahap sebelumnya. Kebutuhan perangkat keras dapat dilihat pada tabel 2. dan kebutuhan perangkat lunak dapat dilihat pada tabel 3 .
Tabel 2. Kebutuhan Perangkat Keras

\begin{tabular}{llc}
\hline No & \multicolumn{1}{c}{ Komponen } & Jumlah \\
\hline 1 & Mikrokontroller NodeMCU & 1 \\
& ESP12E & \\
2 & RFID RC522 & 1 \\
3 & Solenoid Door Lock 12V & 1 \\
4 & Relay 1 Channel & 1 \\
5 & Magnetic Sensor MC38 & 1 \\
6 & Buzzer & 1 \\
7 & Battery Holder 3x18560 & 1 \\
8 & Baterai 18560 & 3 \\
9 & Battery Holder 9V & 1 \\
10 & Baterai 9V & 1 \\
11 & Kabel Jumper & 30 \\
\hline
\end{tabular}

Sumber: (Ridho Syukuryansyah et al. 2020)

Berikut merupakan tabel kebutuhan perangkat lunak dalam menerapkan RFID pada sistem keamanan dan monitoring smart lock door berbasis website.

Tabel 3. Kebutuhan Perangkat Lunak

\begin{tabular}{clc}
\hline No & \multicolumn{1}{c}{ Komponen } & Versi \\
\hline 1 & XAMPP & 5.6 .8 \\
2 & Arduino IDE & 1.8 .9 \\
3 & PHP & 5.2 .0 \\
4 & CodeIgniter & 3.1 .1 \\
5 & MySQL & 5.6 .24
\end{tabular}

Sumber: (Ridho Syukuryansyah et al. 2020)

Pada tahapan ketiga yaitu Modelling Quick Design dalam tahapan ini Tahap ini membagi 3 pemodelan perancangan yaitu, perancangan perangkat keras, perancangan perangkat lunak dan perancangan sistem secara keseluruhan. Berikut masing-masing model perancangannya (Sani et al., 2020).

Dalam pemodelan perancangan sistem keseluruhan menjelaskan cara kerja sistem secara keseluruhan yang akan dibangun. Adapun percancangan sistem keamanan dan monitoring smart lock door berbasis RFID (Radio Frequency Identifitcation) dan Website. 


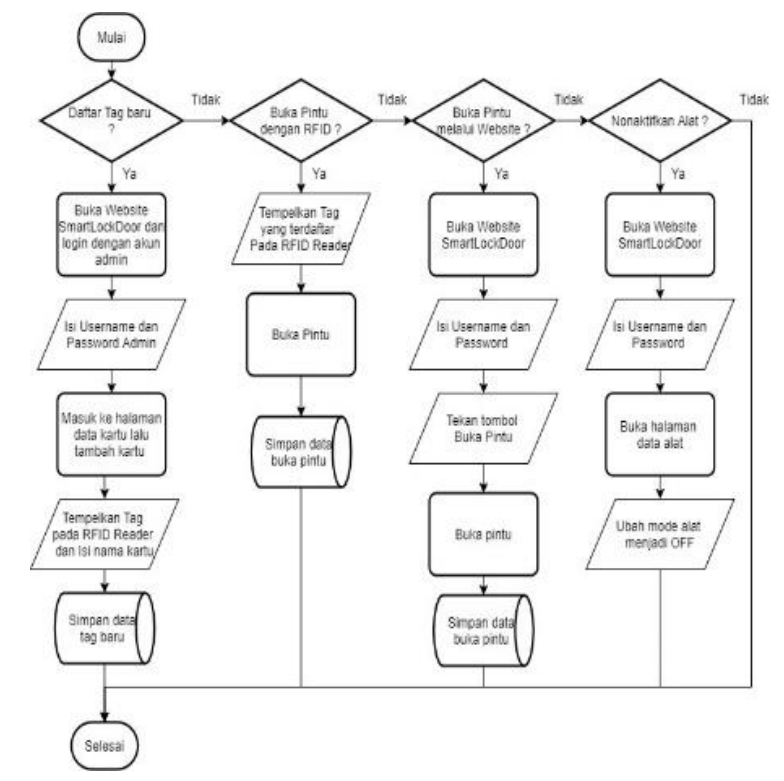

Sumber: (Ridho Syukuryansyah et al. 2020) Gambar 3. Flowchart Sistem Usulan

Kemudian untuk pemodelan perancangan perangkat keras merupakan perancangan rangkaian perangkat keras (hardware) yang akan digunakan dalam sistem keamanan dan monitoring smart lock door berbasis RFID dan Website ini digambarkan dalam bentuk diagram wiring digital.

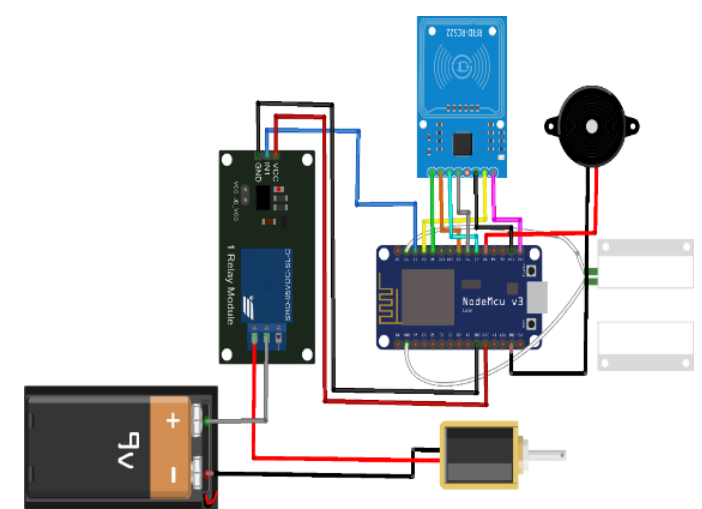

Sumber: (Ridho Syukuryansyah et al. 2020)

Gambar 4. Diagram Wiring Rancangan Perangkat Keras keseluruhan

Dalam gambar 5 merupakan rangkaian perangkat keras yang terdiri dari perancangan Rangkaian Mikrokontroller yang digunakan pada perancangan adalah NodeMCU ESP12E yang telah dilengkapi modul wifi ESP8266 didalamnya. NodeMCU berfungsi untuk menghubungkan komponen lainnya dengan website melalui koneksi wifi (internet), memprogram otentikasi Tag atau kartu dengan RFID, memprogram nyala atau mati nya buzzer sebagai alarm jika terdapat otentikasi yang tidak sah.
Kemudian perancangan RFID berfungsi untuk mendeteksi Tag atau kartu yang memiliki chip di dalamnya, sedangkan untuk otentikasi dalam menentukan sah atau tidaknya akses dilakukan oleh mikrokontroller NodeMCU ESP12E, sehingga alat ini perlu dihubungkan dengan NodeMCU. Selanjutnya perancangan selenoid Door Lock Sebagai kunci elektrik Solenoid Door Lock membutuhkan listrik 12V untuk dapat beroperasi, listrik tersebut didapat dari baterai $12 \mathrm{~V}$, supaya kunci ini dapat dikontrol dan diprogram oleh NodeMCU maka, diperlukan sebuah Relay 1 channel yang berfungsi sebagai jembatan antara NodeMCU dan Solenoid Door Lock.

Kemudian pada rangkaian sensor magnetik MC38 mempunyai dua buah kabel yang bersifat nonpolar, artinya tidak mempunyai kutub poitif dan negatif sehingga bebas menentukan kabel yang akan dijadikan $G N D$ ataupun Inputnya. Dan tahapan terakhir adalah perancangan rangkaian Buzzer, apabila pintu dibuka tanpa otentikasi yang legal dengan melalui $R F I D$ ataupun website maka, Buzzer akan berbunyi sebagai alarm bahwa terdapat otentikasi yang illegal sehingga dapat mengambil perhatian dari orang orang disekitarya yang mendengar sebagai tanda bahaya. Jenis buzzer yang digunakan pada penelitian ini adalah Magnetic Buzzer, yang memiliki dua pin yaitu pin $V C C$ dan pin Output. Pin VCC pada Magentic Buzzer berfungsi sebagai penyuplai arus listrik disambungkan dengan pin $3.3 \mathrm{~V}$ pada NodeMCU, sedangkan untuk pin output dari Magnetic Buzzer ini dihubungkan dengan pin D8 pada NodeMCU.

Dalam rancangan perangkat lunak ini digambarkan alur dari skema perangkat lunak secara keseluruhan. Sehingga dapat tergambar jelas bagaimana alur pembukaan kunci baik dari website ataupun dari alat, ataupaun konfigurasi alat dari laptop/hp melalui website

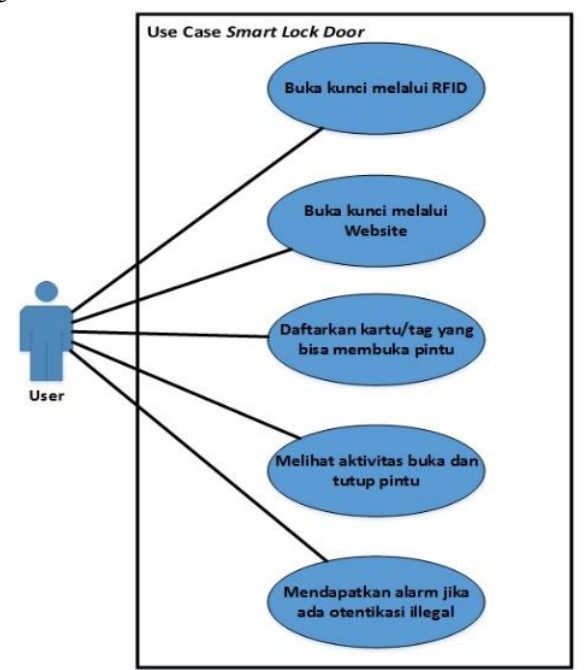

Sumber: (Ridho Syukuryansyah et al. 2020)

Gambar 5. Use Case Diagram Smart Lock Door 
Interaksi antara pengguna dengan alat Smart Lock Door ini akan digambarkan dalam use case diagram ini. Adapun alat Smart Lock Door tersebut terdiri dari NodeMCU sebagai kontrol pusat yang mengelola semua rangkaian input dan output dari sensor yang ada yaitu, RFID (Radio Frequency Identification), relay 1 channel, Solenoid Door Lock, sensor MC38, dan buzzer. User membuka pintu melalui RFID dengan menempelkan kartu sebagai input kepada NodeMCU, kemudian NodeMCU mengirim request kepada server untuk otentikasi kartu, apabila kartu tersebut terdaftar dalam sistem maka NodeMCU membuka Solenoid Door Lock melalui relay 1 channel dan pintu akan terbuka. Begitupun jika melalui website, user login kedalam website dan menekan tombol buka kunci untuk membukanya. Selain untuk membuka pintu, website smart lock door dapat digunakan untuk mendaftarkan user baru untuk login. Selain itu mode pada RFID dikontrol melalui website ini, terdapat dua mode yaitu scan untuk membaca kartu RFID dan mode add sebagai mode untuk mendaftarkan kartu RFID baru. Untuk melakukan mendaftarkan kartu baru dilakukan dengan cara menempelkan kartunya pada RFID setelah itu tambahkan informasi nama pada kartu tersebut pada website.

Untuk mendaftarkan kartu atau tag $R F I D$ yang diperbolehkan untuk masuk melalui RFID. Aktivitas buka atau tutup pintu dapat dilihat pada website. Sensor MC38 bertindak sebagai input untuk mendeteksi apabila pintu terbuka tanpa melakukan otentikasi kartu pada RFID ataupun melalui website sedangkan buzer akan memberikan peringatan berupa alarm pada saat itu. Use Case Diagram Smart Lock Door ini tersaji pada gambar 5.

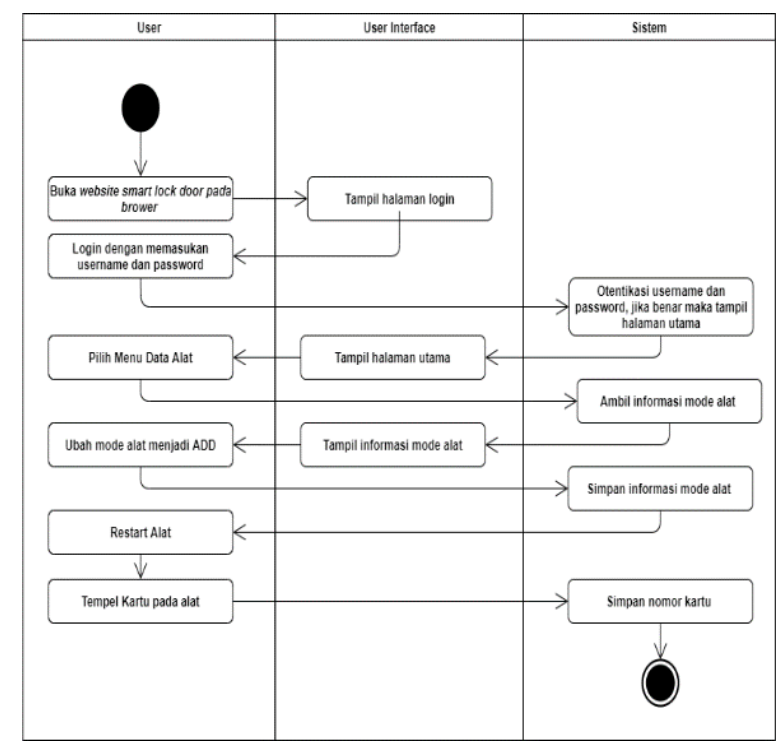

Sumber: (Ridho Syukuryansyah et al. 2020)

Gambar 6. Use Case Diagram Smart Lock Door
Pada gambar 6 merupakan aktivitas untuk mendaftarkan Tag baru pada sistem. Dimulai dengan membuka website smartlockdoor dan login jika login berhasil maka akan diarahkan pada halaman utama, setelah itu pilih menu data alat dan ubah mode alat menjadi add kemudian restart alat dan tempel Tag pada alat maka nomor kartu atau tag akan didaftarkan pada sistem dan siap digunakan untuk membuka pintu.

\begin{tabular}{|c|c|c|c|c|c|c|c|c|c|}
\hline \multicolumn{5}{|c|}{ Logelktinitas } & \multicolumn{5}{|c|}{ Log Aktivitas } \\
\hline N10. & 10log & Status & $\mathrm{sm}$ & Thengal & No. & $10 \log$ & Status & $\mathrm{Jam}$ & Tangsil \\
\hline 1 & 104 & tulapolss & 23:34: & 20000625 & 1 & 105 & bukposisa & 1401:104 & 200007072 \\
\hline 2 & 103 & bizaples & asoman & $20000=25$ & 2 & 204 & bulapasese & 23:31:41 & 20000025 \\
\hline 3 & 102 & thepp & $230 \times 2$ & 20000625 & 3 & 103 & bukposcse & 23:30222 & 20000625 \\
\hline 4 & 101 & bova & 20956 & 20000625 & 4 & 102 & totup & 2330.02 & 20200625 \\
\hline 5 & 100 & 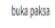 & 20202 & 2000065 & 5 & 101 & buta & 2329.56 & 202000625 \\
\hline 6 & 9 & 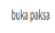 & $2325: 45$ & 2000625 & 6 & 1200 & bula pessa & 23238:12 & $200006-25$ \\
\hline 7 & $\%$ & thapalses & $2 m a$ & 2000625 & 7 & 99 & bukaposes & 2322545 & 200000625 \\
\hline
\end{tabular}

Sumber: (Ridho Syukuryansyah et al. 2020)

Gambar 7. Pencatatan Log

Kemudian tahapan selanjutnya adalah pengujian dilakukan beberapa pengujian salah satunya yaitu pengujian dilakukan dengan membuka pintu tanpa otentikasi melalui RFID ataupun website, namun dengan cara dibuka secara paksa yang kemudian berhasil hingga pintunya terbuka pada sisi sebelah kiri (kotak berwarna jingga) menunjukkan data terakhir sebelum dilakukan pengujian. Pengujian ini dilakukan dengan menjauhkan kedua magnet dari sensor MC38. Setelah itu, sistem mencatat adanya pembukaan paksa pada 2020-07-02 jam 14:01:04 (kotak berwarna merah) disajikan pada gambar 7.

Selain mencatat peristiwa tersebut pada log, sistem juga akan membunyikan buzzer dengan bunyi panjang sebanyak 30 kali sebagai respon sistem atas peristiwa pembukaan pintu secara paksa atau tanpa otentikasi melalui RFID ataupun melalui website. Selain suara melalui buzzer sistem juga akan mengirimkan notifikasi email kepada pemilik sistem.

\section{KESIMPULAN}

Berdasarkan hasil penelitian dapat disimpulkan, prototype merupakan sistem keamanan dan monitoring smart lock door berbasis website ini berhasil dibangun menggunakan mikrokontroller NodeMCU ESP12E, RFID, sensor magnetik MC38, relay, solenoid door lock, dan buzzer yang berfungsi dengan baik sebagai alat otentikasi untuk mengakses dan mendeteksi akses pintu illegal yang dibuka secara paksa tanpa otentikasi. Monitoring terhadap aktivitas pembukaan pintu dan peringatan terhadap akses pintu illegal dapat dilihat pada 
website yang dapat diakses dari mana saja dan kapan saja, dengan syarat telah terdaftar pada sistem dan melakukan login pada website. Dan peringatan terhadap akses illegal berupa bunyi dari buzzer berfungsi dengan baik. Begitu juga dengan peringatan melalui email, email peringatan terkirim dan berada pada kotak masuk secara real time atau pada saat itu juga.

\section{DAFTAR PUSTAKA}

Ade Davy Wiranata, \& Irwansyah, Agus Budiyantara, A. S. (2020). Dan Topsis Employee Candidate Selection Using the Saw and Topsis. 3(1), 22-35.

Agus Budiyantara, Irwansyah, Egi Prengki, P. A. P. (2020). Komparasi Algoritma Decision Tree, Naive Bayes Dan K-Nearest Neighbor Untuk Memprediksi Mahasiswa Lulus Tepat Waktu.

Ahyadi, Z. (2018). Belajar Antarmuka Arduino Secara Cepat Dari Contoh. Poliban Press.

Daulay, N. K., \& Alamsyah, M. N. (2019). Monitoring Sistem Keamanan Pintu Menggunakan Rfid Dan Fingerprint Berbasis Web Dan Database. Jusikom: Jurnal Sistem Komputer Musirawas, 4(02), 85-92. https://doi.org/10.32767/jusikom. v4i2.632.

Galih Surono, N. N. P. (2020). Sistem Pendukung Keputusan Penentuan Siswa Teladan Menggunakan Metode Simple Additive Weighting (SAW) Studi Kasus : SD BHAKTI YKKP.
Mulyati Sumardi, S. S. (2019). IoT on Door Security Control Prototypes based RFID and Bluetooth. Jurnal Teknik, 8(Vol 8, No 2 (2019)), 2-7.

Ridho Syukuryansyah, Didik Setiyadi, S. R. (2020). Penerapan Radio Frequency Identification Dalam Membangun Sistem Keamanan Dan Monitoring Smart Lock Door Berbasis Website.

Sani, A. (2018). Analisa Penjualan Retail Dengan Metode Association Rule Untuk Association Rule Untuk Pengambilan Keputusan Strategis Perusahaan : 2(June 2016), 34-50.

Sani, A., Rahman, T. K. A., Budiyantara, A., \& Doharma, R. (2020). Measurement of readiness in IT adoption among SMEs manufacturing industry in Jakarta. Journal of Physics: Conference Series, 1511(1). https://doi.org/10.1088/1742-6596/1511 $/ 1 / 012002$

Setiawardhana, Wasista, S., \& Saraswati, D. A. (2019). 19 Jam Belajar Cepat Arduino: Edisi Revisi. Bumi Aksara.

Sofyan, A. A., Puspitorini, P., \& Baehaki, D. (2017). Sistem Keamanan Pengendali Pintu Otomatis Berbasis Radio Frequency Identification ( RFID ) Dengan Arduino Uno R3. Jurnal Sisfotek Global, 7(1), 35-41.

Yudhanto, Y., \& Azis, A. (2019). Pengantar Teknologi Internet of Things (IoT). UNS Press. 
